\title{
Teaching Autonomy and Speaking Skill: A Case Study of Iranian EFL Learners
}

\author{
Alireza Mousavi Arfae \\ Faculty of Education, University of Western Ontario, Canada
}

\begin{abstract}
English speaking proficiency requires more than knowing its grammatical and semantic rules. It also includes the knowledge of how native speakers of one language use the language in the context of structures of interpersonal exchange in which many factors interact. In this study, autonomy was implemented by journal or diary writing, sharing and discussing journals, sharing feedback on journals, reflection, promoting dictionary use, introducing useful internet websites, forming yahoo groups, sharing valuable links, creating online self-access center, watching preferable movies, and goal setting. The present quasi-experimental study aimed to investigate the impact of teaching autonomy on the speaking skill of Iranian EFL learners. To this end, 44 male and female intermediate students at Respina Talk (i.e., IranCanada) language school with the age range of 20-35 were selected in order to achieve the objectives of the study. According to the obtained results, there was a significant relationship between teaching autonomy and EFL learners' speaking skill. The findings of this study may have some theoretical and practical implications for material developers, EFL teachers, language learners, etc.
\end{abstract}

Index Terms - teaching, autonomy, speaking Skill, EFL Iranian learners

\section{INTRODUCTION}

For years, pedagogical circles in ELT have been striving to better the existing methods as well as forging new ones that house a variety of recipes aimed at facilitating the teaching-learning process of language skills. Because of its importance, the speaking skill of the learners has received considerable attention of the scholars in the field. Baily and Savage (1994) declare, speaking in a second and foreign language has often been viewed as the most demanding of four skills. ELT theoreticians have accordingly been trying to conjure up the means necessary to help EFL or ESL learners learn how to speak a foreign language (see Arfae, 2020).

Other scholars have as well cited the importance of speaking in the ESL or EFL learning and teaching; for instance, Lazaraton (1996, p. 151) says, "For most people, the ability to speak a language is synonymous with knowing that language, since speech is the most basic means of human communication." Although such strong statements have drawn extents of controversy, arguing their validity, they have mostly been concurred upon in their assertion of the significance of the oral proficiency of the language learners. Nunan (1999) rather poetically describes listening as the "Cinderella skill" in second or foreign language learning and yet speaking as the "elder sister" (see Arfae, 2020).

A wide range of strategies has been concocted and examined to the purpose of helping EFL or ESL learners with their speaking skill. Not all of them, however, have proven successful. The relentless efforts of the scholars in the field, nevertheless, continue to churn new ideas to be added to the array of the existing ones (see Arfae, 2020).

One of rather recent such off-springs happen to be autonomy. Benson (2006) says that Little (2000a, p. 69) combines Holec's (1981) definition with his to provide his recent definition. Autonomy in language learning depends on the development and exercise of a capacity for detachment, critical reflection, decision making and independent action (Little, 1991). Autonomous learners assume responsibility for determining the purpose, content, rhythm, and method of their learning, monitoring its progress, and evaluating its outcomes. (Holec, 1981)

In this study, autonomy was implemented by journal or diary writing, sharing and discussing journals, sharing feedback on journals, reflection, promoting dictionary use, introducing useful internet websites, forming yahoo groups, sharing valuable links, creating online self-access center, watching preferable movies, and goal setting.

Benson (2006) says the history of autonomy in language education begins with the Council of Europe's Modern Language Project that led to the publication of Holec's (1981) seminal report in which autonomy was defined. The origins of the concept, however, seem to belong to decades before hinted by humanistic studies the applications of which placed sizable emphasis on self-directed and self-regulated learning. Benson (2006) also points to the controversies about a dichotomy between 'learner autonomy' as an attribute of the learner and 'autonomy' as a learning situation. Dickinson (1987, p. 11) for instance points to the latter mentioning "the situation in which the learner is responsible for all the decisions, concerned with his learning and the implementation of those decisions". In another interpretation, Allwright (1988, p. 35) said "the idea of learners' autonomy was for a long time associated with a radical restructuring of language pedagogy that involved the rejection of the traditional classroom and the introduction of wholly new ways of working". 
Since its introduction to language pedagogical circles, promoting learner autonomy in language classrooms has been the subject of heated debates and arguments and has accordingly found many proponents and opponents. Recent studies, however, have weakened the position of the opponents. Benson (2001, p. 2) makes the argument that autonomy has its roots in learners' natural tendency to take control of their learning. While asserting that autonomous learning is more effective than regular learning, Benson (2001) further says that if the circumstances are appropriate, learner autonomy can be promoted even among those who do not possess it.

In mainstream ELT contexts, as Pennycook (1994, p. 35) maintains, autonomy is "a matter of helping students to find a voice in English". According to Benson (2006), the concept of autonomy has undergone some modifications since its birth and evolved towards classroom applications, leading to the proliferation of self-access centers and the advent of computer-based modes of teaching and learning. The latest interpretations and implications of autonomy have led to the reshaping of language learning classrooms and courses. The International Association of Applied Linguistics (AILA) Review also has confirmed the efficacy of promoting and fostering learner autonomy in language classrooms in a special issue. To mention another scholar, vouching for the benefits of autonomous learning, one can observe Dam (2001), describing autonomy as an issue of general concern in second language learning. Note should be taken that regulating and directing the language learners do not imply leading them toward isolation and a distrust of language classrooms. On the contrary, as Benson and Voller (1997) put it, learner autonomy must be conceptualized as pedagogical ideology in favor of a teaching that ultimately turns control of the task of learning over to the learners so that they become empowered to engage in learning, independently.

The relentless endeavors of the scholars in the field have shed some light on the importance of the role of the learners in second or foreign language classrooms. Wenden (2002) describes shifting responsibility to the learners and the premium placed on the role of the learners and not the teacher in the language learning process as one of the most important results of the more communicatively-oriented language learning and teaching. Furthermore, a cursory look at the contents page of the recent books on ELT such as Harmer (2007), Hedge (2000), Thornbury (2005) and many others reveals the importance attached to autonomy in mainstream ELT.

The advent of albeit controversial issue of autonomy has reanimated the EFL or ESL classrooms with their practical implications for the teaching or learning process. Teaching the speaking skill as one of the most important skills in language learning has undergone so many a change and alteration in the history of language teaching-learning (see Arfae, 2020). The current trends have distanced from the teacher-the authority, teacher-centered classes in which the students were regarded as subjects, exposed to a certain methodology of teaching practiced by the teacher to which they had to be attuned. The behaviorist or structuralist school implemented in foreign or second language methodologies has waned and has been superseded by the schools that respect cognition. The learner's role and reflection surfaced as crucial to the bipartisan teaching-learning process (see Arfae, 2020).

Based on the above-mentioned issues, the following research question was posed:

Research Question: Is there any significant relationship between the impact of teaching autonomy, and EFL learner's speaking skill?

In order to investigate the research question, the following null hypothesis was put forward:

Null Hypothesis: There is no significant relationship between the impact of teaching autonomy and EFL learner's speaking skill.

Given the fact that the researcher or teacher carried out the study in a language school; he had to comply with the regulations and conditions of the institution. The number of the male and female students was not equal in the classes and due to the previously mentioned reason the researcher or teacher did not have a say in it. Therefore, gender could act as an intervening variable in this study. In addition, due to the regulations of the language school and the syllabus that had to be covered, the researcher could allocate no more than 45 minutes of each session for the experimental treatment in each group (see Arfae, 2020).

The researcher narrowed down the participants to those with intermediate level of proficiency, since elementary level learners might have proven to be immature in their foreign language for practicing autonomy skills, and at advanced level, the learners might have already obtained the skills. In addition, advanced level students would most probably have mastered the speaking skill and basic level students need a rather more fundamental approach to be able to gain a survival level of speaking proficiency and move further. Furthermore, an acute problem with EFL advanced learners was their occasional failure in generating ideas necessary for producing language (see Arfae, 2020).

\section{The PuRPose AND SignifiCANCE OF StUdy}

Little (2000) says autonomy solves the motivation problem. Autonomous learners, he says, draw on their intrinsic motivation when they accept responsibility for their own learning and commit themselves to developing the skills of reflective self-management in learning; and success in learning strengthens their intrinsic motivation. Autonomy has rather recently been advocated by a vast swathe of the scholars in the field, although its practicality and efficacy has not been fully endorsed by all. The present study aimed to investigate the impact of teaching autonomy on the speaking skill of the EFL learners. In other words, it attempted to see whether there was a significant relationship between teaching autonomy, and EFL learners' speaking skill. 
The ability to communicate has, since time immemorial, been an urgent need of man. Among the language skills needed for a proper communication, the speaking skill has stood out as the most important one. The recent trend of globalization has made the issue even more urgent. Language pedagogical circles have for years been trying to formulate concoctions to ease the process of language teaching and learning (see Arfae, 2020).

The scholars in the field have for years now realized the importance of the role of the learners in learning a foreign language. The era of teacher-centered classes is long gone and the new approaches to language pedagogy attach paramount importance to the role of learners. While promoting learner autonomy, the teacher provides the students with assistance in developing various strategies and skills for self-directed learning, and then gradually gives students increasing responsibility for using and defining these learning strategies for themselves. Furthermore, according to Sliogeriene (2005, p.43), "By allowing students' subjectivity into the educational field, and by making it an expectation, we provide students with an opportunity to experience themselves as the knower, as people who have the right to claim a voice, an identity, an authority. Learning thus becomes an active and meaningful process and one that is about the learner as well as the content area studied. When we invite students to bring themselves into the educational arena, we make it richer for them and for us" (see Arfae, 2020).

The introduction of autonomy into language classrooms has reshaped and reformulated the second or foreign language pedagogy. The growing interest in learner autonomy is evidence to its significance in the field. Benson (2006) says, "in terms of sheer quantity, the literature on autonomy published since 2000 exceeds the literature published over the previous 25 years". Yet, in spite of the considerable quantity of the literature published on both autonomy and its impact on developing language skills including the speaking skill, the sheer magnitude of the influence offers much more room for further research and study in the area. The present research offers practical classroom implementations, as it provides the teacher with an insight to the impact of teaching autonomy on the speaking skill of language learners. The empirical study of the entities discussed will provide those involved in the field of foreign language pedagogy with a new scope toward the teaching or learning process of a foreign language. Accordingly, the present study was an attempt to investigate the impact of teaching autonomy on EFL intermediate learners' speaking skill.

\section{Methodology}

\section{A. Participants}

To conduct the study, the present researcher chose 44 male and female intermediate students at Respina Talk (i.e., Iran, Canada) language school with the age range of 20-35. The participants made up three classes, conveniently sampled and the researcher randomly assigned the treatment of autonomy to them (see Arfae, 2020).

\section{B. Instrumentation}

\section{Speaking tests}

To elicit the data required for the study, two sets of PET speaking tests were administered with one serving as the pre-test conducted before the treatment and the other as the post-test at the end of the treatment. The oral test lasted about 10-12 minutes for each candidate. The PET speaking test consists of four parts. It demonstrates the learner's spoken English as they take part in conversation, asking or answering questions, and talking freely, for example, about their likes and dislikes. The speaking test is conducted face-to-face to make the test more realistic and more reliable. PET speaking section includes the following parts. As the first step, the students were asked to introduce themselves. The participants were asked some general questions. Next, the participants were required to speak about a given topic and the follow-up questions. After that, the participants were given photos and asked to talk about those photos and the follow-up questions. As the last step of the speaking test, the participants engaged in a dialogue with the test giver to arrange for a social event (see Arfae, 2020).

\section{The Oral Proficiency Rating Scale}

To observe objectivity of the measuring process of the speaking test, the present researcher deemed it necessary to make use of an analytic rating scale. He utilized the PET rating scale for scoring the speaking tests. In addition, two raters with a high inter-rater reliability scored the participants' speaking to decrease the subjectivity of scoring as much as possible and each participant's score was the average of the scores given by the two raters. It is worth mentioning that the two raters' inter-rater reliability was estimated from 30 speaking samples that they had previously rated

\section{Instructional Material}

Apart from, yet in line with the treatment randomly assigned to the experimental group, the present researcher or teacher had to follow the syllabus of the language school where he conducted the study. Respina Tak (i.e., Iran Canada) language school offers "Interchange" books as the textbook for the language learners. Four units are covered throughout every term. The participants of the study were at the level of Interchange 3, the third part i.e., the last four units of the book. The book of course provided the learners with audio and video material, utilized in the classroom in accordance with the teacher's guide and in line with the treatment, designated for every experimental group (see Arfae, 2020).

\section{Procedure}


The study aimed to investigate the impact of teaching autonomy on EFL learner's speaking skills. The participants of the study were young adult and adult male and female intermediate learners of EFL at Respina talk (i.e., Iran Canada) language school at Tehran.

The researcher or teacher had one experimental group at his disposal with a total number of 44 participants. Every group was randomly assigned to one of the designated treatments of autonomy. At the first step, a PET speaking test was administered to the participants in the experimental group.

Note should be taken that in order to boost the reliability and minimizing the subjectivity of the results, the speaking performance of the participants both at the pre-test and the post-test were scored by two raters, that is, the present researcher or teacher and his fellow colleague, who was trained by researcher to follow the relevant rating scale. To determine the inter-rater reliability and consistency, prior to administering the PET speaking pre-test, a similar PET speaking test was piloted on 30 participants, enjoying the same qualities as the participants of the study and the interrater reliability of the two raters was estimated based on their scorings.

Once the inter-rater reliability and consistency was determined, the average of the two scores given by the two raters was considered as the score obtained by the participants.

After the speaking pre-test, every experimental group underwent the designated treatment for a total of 10 two-hour sessions. Care was given to the equality of time and amount of the treatment employed so that the amount and time of the exposure to the designated treatment would not tarnish the results of the study. It is noteworthy that due to the regulations of the language school and the syllabus that had to be covered, the present researcher allocated 45 minutes of each session for the experimental treatment in each group (see Arfae, 2020).

\section{Treatment}

The first experimental group was assigned the autonomy treatment. Benson (2001) says fostering autonomy does not imply any particular approach to practice. Bearing that in mind, autonomy of a learner can be fostered through a wide array of activities at disposal of the teacher. The teacher who intends to promote learner autonomy needs to do his utmost to make his/her students independent. To practice the treatment of the present study, the researcher or teacher allocated 10 sessions of the course to fostering autonomy in the first experimental group. To achieve the goal, the researcher or teacher along with the participants went through the following steps:

Session 1:

The researcher or teacher spent a considerable amount of time to establish a strong rapport with the students through the ice-breaking activity. The teacher assumed that in order to open up to the teacher and their peers, the students needed to feel secure. They needed to confide in their teacher and their peers to expound on their self-discovery, expected throughout the course.

The teacher or researcher introduced the concept of autonomy and what was expected of the learners. To do so, he asked the students to be conscious of their learning process throughout the course. The teacher pointed out that there are different learning styles and strategies and that everyone has their own learning style that requires different learning strategies. The teacher described in details the learning journals or diaries and how to start one. Different parts of the journals were discussed in details and the researcher or teacher helped the students with the questions they had concerning their learning journals.

The teacher and the students talked about dictionary use. The teacher introduced several dictionaries, CD-ROMs, as well as hard copies, as the learners were supposed to take charge of their own learning dictionary use was essential.

The teacher asked the students to choose their favorite movie or TV series and discuss it with their peers. The students also had to find out about the ways through which watching a movie could help them with their learning process.

The teacher introduced internet social networks and Yahoo groups. He received the students e-mail addresses and started a Yahoo group later, inviting the students to join them. In the yahoo group, the learners had the chance to openly discuss their learning process and problems, the present researcher or teacher and the students shared valuable links about learning English. The links, shared by the students, served as an online self-access box, as the students were able to download books they needed at will.

The teacher introduced the idea of the students, starting their own English club, where they would meet at different occasions outside the classroom in their desired place for a specific given time and spend their time speaking in English, only discussing their learning as well as their daily life. The students were encouraged by the teacher to devise their own programs for the club, although the researcher could not verify whether the activity was practiced or not. To help the students reflect on their learning process, the teacher had the students talk about their individual goals and objectives. He also asked the students to define new goals for themselves and encouraged them to pursue those goals through collaboration with their peers.

Session 2 through sessions ten:

From session two through session ten, the students began every session with presenting their learning journal to their peers in groups of three, discussing their learning process. As per their teacher's instructions, they came up with different strategies and shared them with their peers. Different elements of language were discussed separately. As instructed by the teacher, the students had assigned themselves to different assignments. The assignment however was chosen by the learners themselves. The students were asked to determine their own assignments besides the routine 
homework given by the teacher. Every two sessions, the students shared their feedback on their assignments with each other and the teacher. As sharing and discussing the learning journals took place among the students in different groups, the teacher randomly joined the groups and meticulously monitored every group member, and giving advice when required. Every two sessions, the students came up with a self-assessment, describing what they had learned. Throughout the course, the students were exposed to a selection, following speaking tasks:

Pair-work discussion: students were required to pick a topic and discuss it in pairs. The notion of the student's independence was important in fostering autonomy. Furthermore, the concept of peer correction was introduced as essential by the teacher. The students were required to carefully monitor their partners, as they spoke and correct them.

Story telling: In groups of three, the students told stories they had either read in a storybook or seen in a movie. Every group had three members: the storyteller, the one who would correct, and the third member who would keep a record of the story and described it to the next group in a rotational manner.

Shadowing in conversation: The teacher presented the students with a line, the students then had to take turns, making another sentence building a story.

Talk-show, free discussion: Both of these activities help students with their fluency, as they overcome their inhibitions and make an effort to speak. The situation resembles that of real life interaction and the students feel distanced from the classroom environment.

In brief, the treatment included the following steps in each session:

Session 1: Ice-breaking activity, introduction of the concept of autonomy, discussing awareness, learning styles and strategies, learning journals, websites, and Yahoo group, discussing students' goals and objectives

Session 2: Sharing journals, discussing issues and problems, describing assignments, the students engaged in a talk show, a pair-work.

Session 3: the students shared journals and discussed their issues and problems. They described their assignments, and presented a self-assessment to their partners in groups of three. As part of the story-telling activity, the students described a movie they had seen recently in pair, peer correction was emphasized; the class had a group discussion on the issue of learning English as a foreign language.

Session 4: After sharing their journals, talking about their assignments and progress, the students gave each other a feedback on using a journal and how it helped them with their learning process. The students took part in shadowing in conversation making up a story; they had a pair work and a free discussion.

The same procedures were carried out through the tenth session. The use of learning journals helped raise the students' consciousness and awareness toward their learning process. The activities and assignments they defined for themselves helped them with taking charge of their own learning. Discussing their favorable strategies with their peers, as they asserted gave them a new scope.

\section{E. Design}

The present study was quasi-experimental with a pretest-posttest design, since there was no chance of randomization of the participants and the groups were selected via convenient sampling. Of course, the choice of treatment for each group was randomly made. The independent variable of the study was the type of treatment namely, autonomy. The dependent variable was the speaking ability of the participants. The gender of the participants can be considered as the intervening variable, since the number of the male and female participants were not equal in the experimental group. The control variable of the study was the language proficiency of the learners according to the categorizations of the language school they were studying in (see Arfae, 2020).

\section{F. Data Analysis}

The SPSS software was used to conduct the statistical analysis, implemented in the present study, as follows:

1. Inter rater reliability estimate of the two raters in the speaking tests

2. Descriptive statistics of the speaking pretest

3. Descriptive statistics of the posttest

4. Checking the assumption of Analysis of Covariance (ANCOVA)

5. An Analysis of Covariance (ANCOVA)

\section{RESULTS AND DisCUSSION}

The first step in statistical analysis was to analyze the data of the speaking pretest of the experimental group. Table 1 presents the descriptive statistics of the speaking pretest conducted prior to the treatment (see Arfae, 2020). 
TABLE 1

DESCRIPTIVE STATISTICS OF THE EXPERIMENTAL GROUPS' SPEAKING PRETEST

\begin{tabular}{|c|c|c|c|c|c|c|c|c|c|}
\hline & $\mathrm{N}$ & Range & Minimum & Maximum & Mean & $\begin{array}{l}\text { Std. } \\
\text { Deviation }\end{array}$ & Variance & Skewness & \\
\hline & Statistic & Statistic & Statistic & Statistic & Statistic & Statistic & Statistic & Statistic & $\begin{array}{l}\text { Std. } \\
\text { Error }\end{array}$ \\
\hline Pre AUTONOMY & 14 & 8.50 & 14.00 & 22.50 & 17.9286 & 2.28589 & 5.225 & .192 & .597 \\
\hline
\end{tabular}

As Table 1 shows, the mean turned out to be 17.92 for autonomy group. In addition, the variance was 5.22. Moreover, the fraction of skewness statistic to its Std. Error was equal to .32 that is between the range of -1.96 and 1.96 , ensuring the normality of the distribution of scores in the speaking pretest for the experimental group.

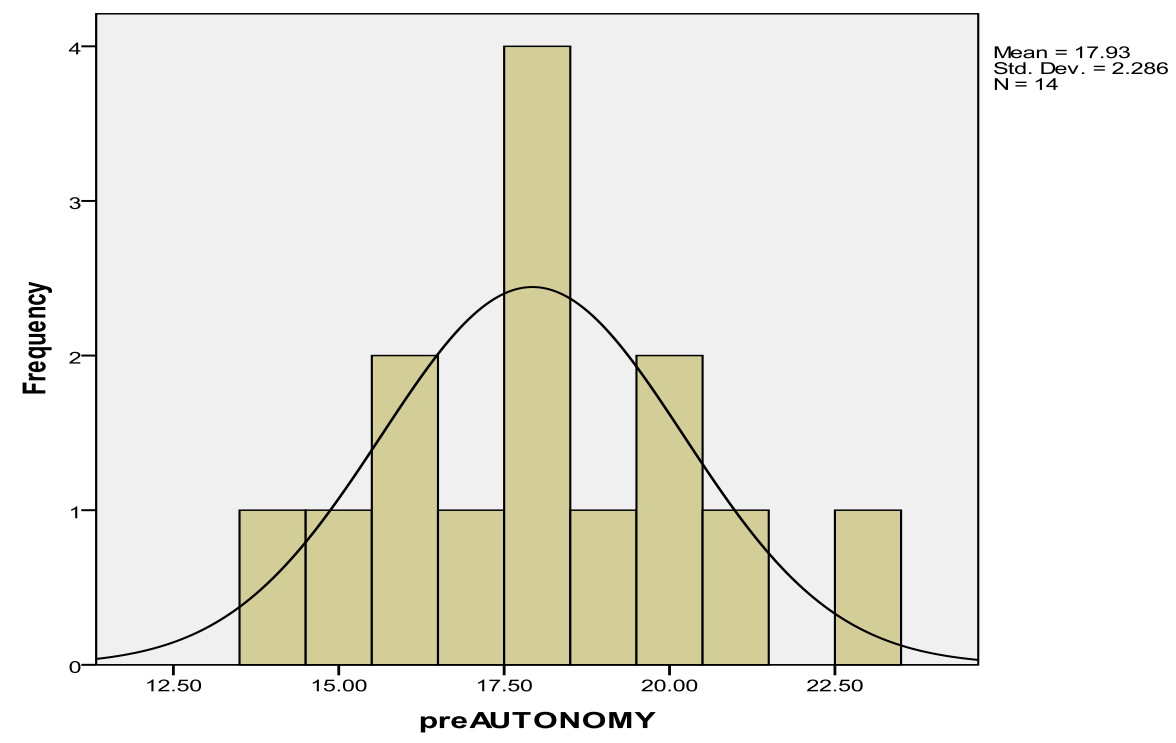

Figure 1. Histogram of Speaking Pretest Scores for Autonomy Group

In order to make sure of the reliability of the test scores, the scores of two raters were correlated to see whether the test was reliable or not. Table 2 provides the information on the inter-rater reliability of the two raters who scored the speaking pretest.

TABLE 2

INTER-RATER RELIABILITY OF SPEAKING PRETEST

\begin{tabular}{llll}
\hline & & rater1 & rater2 \\
\hline rater1 & Pearson Correlation & 1 & $.923^{* * *}$ \\
\cline { 2 - 4 } & Sig. (2-tailed) & & .000 \\
\cline { 2 - 4 } & $\mathrm{N}$ & 50 & 50 \\
\hline rater2 & Pearson Correlation & $.923^{* * *}$ & 1 \\
\cline { 2 - 4 } & Sig. (2-tailed) & .000 & \\
\cline { 2 - 3 } & $\mathrm{N}$ & 50 & 50 \\
\hline **. Correlation is significant at the 0.01 level (2-tailed).
\end{tabular}

As can be seen from Table 2, the two raters demonstrated a high amount of correlation and a reliable measurement. Table 3 presents the descriptive statistics of the speaking posttest, conducted at the end of the treatment period. At the end of the treatment period that took ten sessions, the researcher conducted a speaking posttest to see whether there has been any significant change in the performance of the experimental group. The data are provided in Table 3 (see Arfae, 2020).

TABLE 3

DESCRIPTIVE STATISTICS OF EXPERIMENTAL GROUP’s SPEAKING POSTTEST

\begin{tabular}{|c|c|c|c|c|c|c|c|c|c|}
\hline & $\mathrm{N}$ & Range & Minimum & Maximum & Mean & $\begin{array}{l}\text { Std. } \\
\text { Deviation }\end{array}$ & Variance & Skewness & \\
\hline & Statistic & Statistic & Statistic & Statistic & Statistic & Statistic & Statistic & Statistic & $\begin{array}{l}\text { Std. } \\
\text { Error }\end{array}$ \\
\hline Post t AUTONOMY & 14 & 7.00 & 17.00 & 24.00 & 20.8571 & 1.92582 & 3.709 & -.547 & .597 \\
\hline
\end{tabular}


Table 3 shows a mean of 20.85 and a variance of 3.709 for autonomy group. In addition, the distribution of scores for the experimental group demonstrated normality, because none of the values of the fraction of skewness/Std. error of skewness came out to be out of the range of -1.96 and 1.96 (i.e., 1.28). The normal distributions are manifested in Figures 4, 5, and 6 below (see Arfae, 2020).

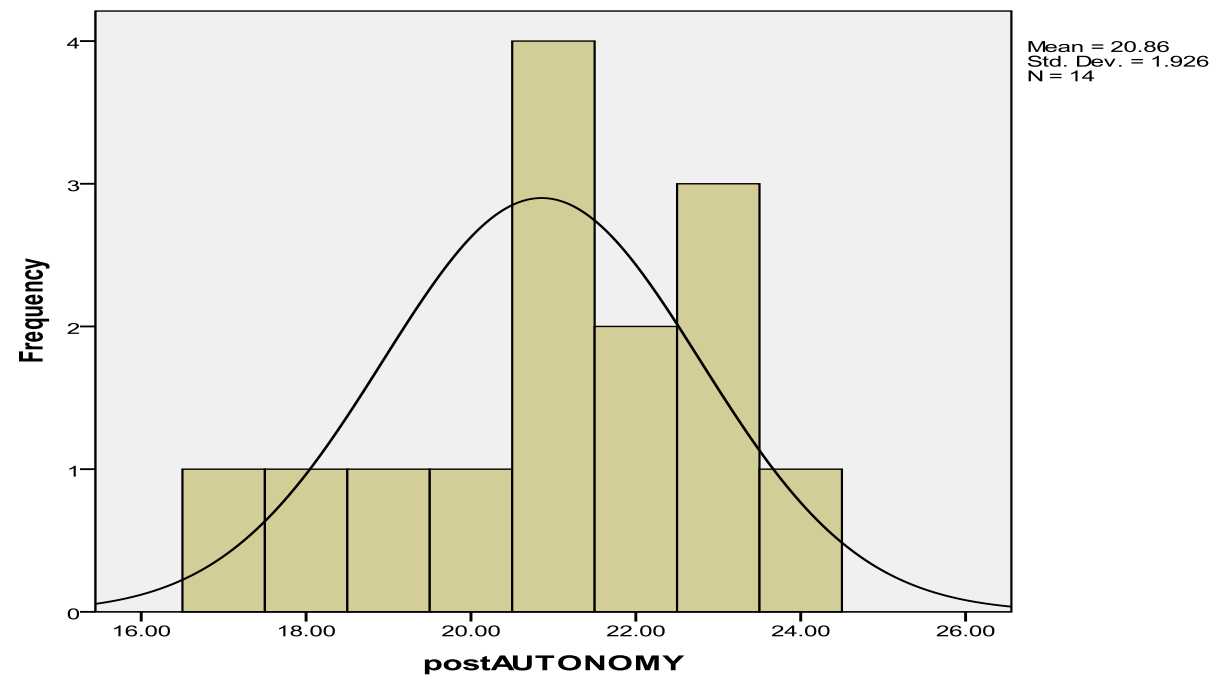

Figure 4 Histogram of Speaking Posttest Scores for Autonomy Thinking Group

Table 4 shows the inter-rater reliability estimate between the two raters of the speaking posttest.

TABLE 4

INTER-RATER RELIABILITY OF SPEAKING POSTTEST

\begin{tabular}{llll}
\hline & & & \\
\hline \multirow{2}{*}{ Rater 1 } & Pearson Correlation & 1 & rater2 \\
\cline { 2 - 4 } & Sig. (2-tailed) & $.933^{* *}$ \\
\cline { 2 - 4 } & $\mathrm{N}$ & 44 & .000 \\
\hline Rater 2 & Pearson Correlation & $.933^{* *}$ & 44 \\
\cline { 2 - 4 } & Sig. (2-tailed) & .000 & 1 \\
\cline { 2 - 3 } & $\mathrm{N}$ & 44 & 44 \\
\hline **. Correlation is significant at the 0.01 level (2-tailed). \\
\hline
\end{tabular}

As can be seen from Table 4, the two raters enjoyed a high level of correlation, ensuring the reliability of the measurement by the researcher. As the number of participants was not large and there was no chance of homogenizing, the participants prior to the treatment without the risk of losing more participants and decreasing the number of the target sample, an analysis of covariance (ANCOVA) was conducted as the referential statistics of the research study and in order to investigate the null hypothesis which stated that there is no significant difference between the impact of Teaching Autonomy on EFL learner's speaking skill (see Arfae, 2020).

However, prior to this analysis, there were a set of assumptions that need to be checked to legitimize conducting an ANCOVA. The independent categorical variable was the treatment provided for the experimental group, the continuous dependent variable was the participants' speaking ability, and the continuous covariate was the pretest scores of the participants on the speaking test conducted prior to the treatment.

The first assumption is the reliability of the covariate that is measured before the treatment and in this case the speaking pretest. As the speaking test was a PET speaking section rated according to the rating scale provided for the test and scored by raters whose inter-rater reliability was assured previously (see Table 3), this first assumption was met (see Arfae, 2020). 
TABLE 5

TESTS OF BETWEEN-SUBJECTS EFFECTS-HOMOGENEITY OF REGRESSION SLOPES

\begin{tabular}{|c|c|c|c|c|c|}
\hline \multicolumn{6}{|c|}{ Dependent Variable: speaking POSTTEST } \\
\hline Source & $\begin{array}{l}\text { Type III Sum of } \\
\text { Squares }\end{array}$ & Df & Mean Square & $\mathrm{F}$ & Sig. \\
\hline Corrected Model & $238.931^{\mathrm{a}}$ & 5 & 47.786 & 64.905 & .000 \\
\hline Intercept & 18.763 & 1 & 18.763 & 25.484 & .000 \\
\hline GROUP & 1.229 & 2 & .614 & .834 & .442 \\
\hline Speaking PRETEST & 202.439 & 1 & 202.439 & 274.958 & .000 \\
\hline GROUP $*$ speaking PRETEST & .970 & 2 & .485 & .659 & .523 \\
\hline Error & 27.978 & 38 & .736 & & \\
\hline Total & 18840.000 & 44 & & & \\
\hline Corrected Total & 266.909 & 43 & & & \\
\hline a. $\mathrm{R}$ Squared $=.895$ (Adjusted $\mathrm{F}$ & ared $=.881)$ & & & & \\
\hline
\end{tabular}

As the output obtained from Table 5 indicates, the value of significance level of the interaction term (shown above as GROUP*speaking pretest) is .523 which is larger than .05 indicating that the assumption has not been violated. Bearing in mind that the normality of the distributions of scores in both speaking pretest and posttest was previously checked and ensured, and with all assumptions of legitimizing ANCOVA met, the researcher felt confident to embark on the analysis. Tables 6, 7, present the results (see Arfae, 2020).

TABLE 6

DESCRIPTIVE STATISTICS OF SPEAKING POSTTEST

\begin{tabular}{llll}
\hline \multicolumn{4}{l}{} \\
Dependent Variable: speaking POSTTEST & & \\
\hline GROUP & Mean & Std. Deviation & $\mathrm{N}$ \\
\hline AUTONOMY & 20.8571 & 1.92582 & 14 \\
\hline
\end{tabular}

As can be seen from Table 6, the mean was 20.85 for the autonomy group. In addition, the standard deviation came out as 1.92. Table 7 presents the Levene's test of equality of error variance.

TABLE 7

LEVENE'S TEST OF EQUALITY OF ERROR VARIANCES

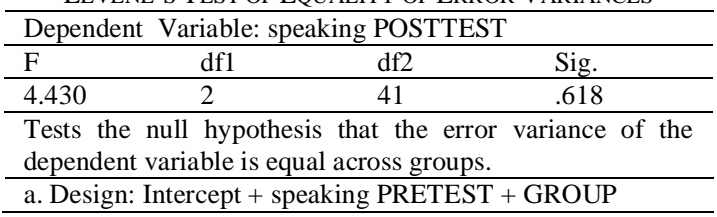

According to Table 7, the Sig. value (i.e., 0.618) was larger than .05 showing that the assumption of homogeneity of variance was not violated.

Table 8 presents the main ANCOVA results. It shows whether the groups were significantly different in terms of their scores on the speaking posttest (dependent variable) (see Arfae, 2020).

TABLE 8

TESTS OF BETWEEN SUBJECTS EFFECTS

\begin{tabular}{|c|c|c|c|c|c|c|}
\hline \multicolumn{7}{|c|}{ Dependent Variable: speaking POSTTEST } \\
\hline Source & $\begin{array}{l}\text { Type III } \\
\text { Squares }\end{array}$ & df & Mean Square & $\mathrm{F}$ & Sig. & Partial Eta Squared \\
\hline Corrected Model & $237.962^{\mathrm{a}}$ & 3 & 79.321 & 109.607 & .000 & .892 \\
\hline Intercept & 17.938 & 1 & 17.938 & 24.787 & .000 & .383 \\
\hline speaking PRETEST & 223.195 & 1 & 223.195 & 308.415 & .000 & .885 \\
\hline GROUP & 19.786 & 2 & 9.893 & 13.670 & .000 & .406 \\
\hline Error & 28.947 & 40 & .724 & & & \\
\hline Total & 18840.000 & 44 & & & & \\
\hline Corrected Total & 266.909 & 43 & & & & \\
\hline
\end{tabular}

The Sig. value corresponding to the independent variable (GROUP) .000 turned out to be less than .05; therefore, the results are significant and the experimental group is indeed different regarding its performance on the speaking posttest. The partial Eta square was equal to .40 showing that $40 \%$ of the variance of the dependent variable is explained by the independent variable (see Arfae, 2020).

Table 9 presents the estimated marginal means on the dependent variable for each of the groups. Adjusted refers to the fact that the effect of covariate has been statistically removed. 
TABLE 9

ESTIMATED MARGINAL MEANS

\begin{tabular}{|c|c|c|c|c|}
\hline \multicolumn{5}{|c|}{ Dependent Variable: speaking POSTTEST } \\
\hline \multirow[t]{2}{*}{ GROUP } & \multirow[t]{2}{*}{ Mean } & \multirow[t]{2}{*}{ Std. Error } & \multicolumn{2}{|c|}{ 95\% Confidence Interval } \\
\hline & & & Lower Bound & Upper Bound \\
\hline AUTONOMY & $20.769^{\mathrm{a}}$ & .227 & 20.309 & 21.228 \\
\hline
\end{tabular}

As can be seen from Table 9, the mean 20.30 belonged to the autonomy group. Therefore, the null hypothesis of the study was rejected and group with both autonomy intervention (see Arfae, 2020).

\section{DISCUSSION}

A one-way between-group analysis of covariance (ANCOVA) was conducted to compare the effectiveness of the one different intervention designed to improve speaking ability. The independent variable was the type of intervention (i.e., autonomy), and the dependent variable consisted of scores on the speaking posttest administered after the intervention was completed. The speaking pretest was considered as the covariate in this analysis. Preliminary checks were conducted to ensure that there was no violation of the assumptions of normality, linearity, homogeneity of variances, homogeneity of regression slopes, and reliable measurement of the covariate. After adjusting for the pre-intervention scores, there was a significant difference between the groups on post-intervention scores of speaking (see Arfae, 2020).

The analysis of the data elicited clearly rejects the null hypothesis of the research stating that 'There is no significant difference between the impact of Teaching Autonomy on EFL learner's speaking skill.'

The findings of the research are in line with the results presented by a great deal of empirical studies carried out on autonomy. Albeit somehow controversial, the notion of autonomy continues to gain weight. A cursory look at the literature stands evidence that proponents of the autonomy now outnumber the opponents by a large number. Concerning autonomy for instance, Benson (2006) in his state of the art article entitled "Autonomy in language teaching and learning," mentions the growing interest to the teaching of autonomy in language classrooms. While citing works such as Hedge (2000), Harmer (2001), Kumaravadivelu (1991), Nation (2001) and Thornbury (2005), Benson (2006) says that such books provide us with the most striking evidence of the movement of autonomy into mainstream language education.

Material developers have likewise learned about the efficacy of incorporating tasks that promote autonomy. A glance at Jack C. Richards' 'Four Corners' stands proof to the assertion.

The present research however is quite distinctive in that it presents an investigation into the impact of the teaching of autonomy on EFL learners. Naturally, the results have certain implications for pedagogical circles.

\section{CONCLUSIONS, IMPLiCATIONS, AND SUGGESTIONS}

\section{A. Conclusion}

The study aimed at investigating the impact of teaching autonomy on intermediate EFL learners' speaking skill. To this end, the null hypothesis stating that 'There is no significant difference between the impact of Teaching Autonomy on EFL learner's speaking skill' was put to test.

A total number of 44 participants were assigned to one experimental group of autonomy; the participants were assigned to the one experimental groups of Autonomy.

Prior to the treatment, a PET speaking pretest was given to the participants in the experimental group. The participants' performance was recorded using a recording device and then rated by two raters using the same rating scale to minimize the subjectivity of the rating. Then, the experimental group was exposed to the designated treatment that lasted for 10 two-hour sessions. Due to the regulations of the language school, however, the researcher or teacher could allocate no more than 45 minutes of every session to the treatment. Upon the conclusion of the treatment, a PET speaking posttest was administered. The same mechanism as the pretest was employed in the rating of the participants' performances at this stage. In order to study the impact of the independent variable an analysis of covariance ANCOVA was conducted as the referential statistics of the research study. While providing the opportunity to study the participants' performances prior and after the introduction of the relevant treatment designated for the experimental group in an individual level as well as a whole experimental group the application of ANCOVA obviated the need of a homogenization process which would lead to a significant participant loss as the number of the participants was relatively small. Certain assumptions were investigated to legitimize the application of an ANCOVA. Once the assumptions were met, the researcher felt confident to embark on the analysis.

The study aimed to investigate the impact of teaching of autonomy. The results presented clearly rejected the null hypothesis, revealing significant differences among the impact of teaching of the independent variable (see Arfae, 2020).

At the end of the treatment period that took ten sessions, the researcher conducted a speaking posttest to see whether there has been any significant change in the performance of the experimental group (i.e. Autonomy group). There was a mean of 20.85 for autonomy group. The variance was 3.709. The null hypothesis was clearly rejected. 
The study aimed to investigate the impact of teaching autonomy upon the EFL intermediate learners. The results of the study serve the enthusiast teachers and material developers as a device to better their work. The analysis of the data collected throughout the study stand as evidence to the assertion.

Note should be taken however, that due to the language school's regulation where the study was carried out, the researcher or teacher could allocate no more than 45 minutes of each session to the treatment. Had the limitation not been there, the results of the study might have turned out differently (see Arfae, 2020).

\section{B. Implications}

The analysis of the data elicited through the previously mentioned mechanisms, proved the significant difference the implementation of the treatment made in each participant. The outcome reveals the importance of fostering the language learner autonomy. The proper implementation of the concoction as concluded by the research results will definitely ensure a better performance on the part of the learners while increasing the efficacy of the process. The findings of the study while consistent with the assertions of the scholars advocating autonomy highlight the efficacy of the fostering of learner autonomy. Accordingly, the researcher makes the following recommendations (see Arfae, 2020):

- Teachers must be made aware of the concepts autonomy. Teacher training courses need to familiarize language teachers with the strategies and techniques applicable in fostering learner autonomy.

- Material developers need to promote learner autonomy through provision of tasks that help the teachers and learners to that end.

- The learners also need to be made aware of the concepts of autonomy. They also need to learn about selfregulation and discovery learning. While being encouraged to think for themselves, the learners need to gradually take charge of their own learning.

- Establishing positive teacher-student, student-student rapport, creating a convivial environment and promoting cooperative/collaborative learning should be highlighted in language classrooms. They act as catalyst in promoting learner autonomy.

\section{Suggestions for Further Research}

In spite of the growing interest in the concepts of autonomy, as Benson (2006) says, it has to be acknowledged that the empirical knowledge base on autonomy in language learning remains somewhat week. In pedagogical circles helping facilitate the teaching or learning of a foreign language. The following may serve the enthusiastic research as potential grounds to cover (see Arfae, 2020):

- Even though an assumption on the part of the researcher was that the elementary learners of a foreign language might lack the maturity necessary for being exposed to the treatment of the study or that the advanced learners might have already obtained or developed, it might prove useful to include those levels in further research.

- The limitation concerning the number of participants of the study is an issue worth considering. Further studies with large numbers of participants may be carried out to assess the findings of the study (see Arfae, 2020).

- The study was carried out in a private language school where the participants willingly took part in EFL classrooms. The level of motivation of the learners in such an environment would in all likelihood differ from that of the EFL learners in other educational institutions including schools. Further research may be carried out in other educational facilities.

- Due to the age limitation dictated by the language school, where the study was conducted, children were excluded from the study.

- Further study may be carried out to investigate the impact of teaching autonomy on other dependent variables specifically other language skills, i.e. reading, writing and listening.

- Due to the regulations of the language school and the syllabus that had to be covered, the researcher allocated 45 minutes of each session for the experimental treatment. Further study may be carried out to investigate the result of longer exposure to the treatments (see Arfae, 2020).

\section{REFERENCES}

[1] Allwright, D. (1988). Autonomy and individualization in whole-class instruction. Individualization and autonomy in language learning, 35-44.

[2] Arfae, A. M. (2020). The Impact of Teaching Critical Thinking on EFL Learners' Speaking Skill: A Case Study of an Iranian Context. English Language Teaching Archives, 13, 1. 112-123.

[3] Benson, P. (1997). The philosophy and politics of learner autonomy. In Benson \& Voller (Eds.), Autonomy \& independence in language learning (pp. 18-34). London: Longman.

[4] Benson, P. (2001). Teaching and researching in language autonomy in language learning. London: Longman.

[5] Benson, P. (2006). Autonomy in language teaching and learning. Language Teaching, 40, 21-40.

[6] Benson, P. \& Voller, P. (1997). Autonomy \& independence in language learning. London: Longman.

[7] Dam, L. (2001). Learner autonomy: new insights. AILA Review 15.

[8] Dickinson, L. (1987). Self-instruction in language learning. Cambridge: Cambridge University Press.

[9] Harmer, J. (2001). The practice of English language teaching. London: Longman.

[10] Harmer, J. (2007). How to teach English (second Ed.). London: Pearson Education Ltd. 
[11] Hedge, T (2000). Teaching and learning in the language classroom. London: Oxford University Press.

[12] Holec H. (1981). Autonomie et apprentisage des langues etrangeres Strasbourg: Council of Europe [Autonomy in Foreign Language learning]. Oxford: Pergamon.

[13] Kumaravadivelu, B. (1991). Language-learning tasks: teacher intention and learner interpretation. ELT Journal 45/2.

[14] Lazaraton, A. (1996). Interlocutor Support in Oral proficiency interviews. Language Testing, 13, 151-172.

[15] Nunan, D. (1999). Second language teaching and learning. Boston: Heincle \& Heincle Publishers.

[16] Pennycook, A. (1994). Cultural alternatives and autonomy. In Benson \& Voller (Eds.), Autonomy \& independence in language learning (pp. 35-53). London: Longman.

[17] Sliogeriene, J. (2005). Promoting Effective Thinking in ESP Teaching. Acta Paedagogica Vilnensia, (14), 199-207.

[18] Thornbury, S. (2005). How to Teach Speaking Pearson Education Ltd.

[19] Weiner, B. (2006). Attribution theory. Retrieved September 4, 2006, from World Wide Web: http://tip.psychology.org/weiner.html.

[20] Wenden, A. (2002). Learner development in language learning. Applied Linguistics, 23, 32-55.

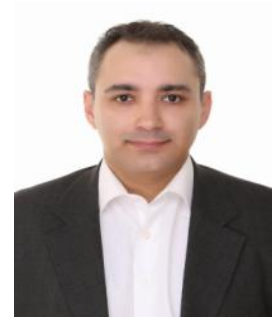

Alireza M. Arfae is an educator/researcher in the field of second language education. He has conducted extensive research in ESL/EFL contexts on Learner Autonomy and Critical Thinking as his areas of interest. His $\mathrm{PhD}$ research explores the promotion Language Learner Autonomy in the Canadian province of Ontario's ESL context. His thesis in fulfillment of Master's degree in English Language Teaching investigates the impact of fostering learner autonomy and critical thinking on EFL learners' speaking skill. Dr. Arfae received his $\mathrm{PhD}$ in "Education Studies, Curriculum and Pedagogy" from Western University (UWO) in Ontario, Canada. His teaching philosophy is founded on empowering learners by helping them find their voice through their learning experience. 